\title{
From a Student of Startup Business to a Startup Employee or Entrepreneur: Study on Career Narratives of Students in Entrepreneurial Programs in a University
}

\author{
Juha Saukkonen (Corresponding author) \\ School of Business and Services Management \\ JAMK University of Applied Sciences, Jyväskylä, Finland \\ E-mail: juha.saukkonen@jamk.fi
}

Received: April 25, 2016 Accepted: June 23, 2017 Published: June 29, 2017

doi:10.5296/jei.v3i1.11117 URL: https://doi.org/10.5296/jei.v3i1.11117

\begin{abstract}
The purpose of this research is to gain an understanding of the incidents, relationships and processes that support entrepreneurial students to become employees and entrepreneurs. Through a qualitative approach based on career history and projections written by the respondents, this study aims to shed light on the process of becoming an entrepreneur or employed by an entrepreneurial organization. Pedagogical and professional issues that may foster the development of these practices eventually leading to employment and entrepreneurial activities are posed.
\end{abstract}

\section{Introduction}

The BBC, 2013 internet newsfeed: "Brian Morgan, professor of entrepreneurship at Cardiff Metropolitan University, says that while inherited genetic factor play an important role in creating successful entrepreneurs, most still need to be taught other vital skills. In general, about $40 \%$ of entrepreneurial skills can be thought of as 'in the DNA'. But $60 \%$ of the competencies required to create a successful and sustainable business - such as technical and financial expertise - have to be acquired." (BBC, 2013)

New firms based on entrepreneurial effort are recognized globally as the key engine of wealth and employment creation. Numerous university programs and courses aim at betterment of conditions for entrepreneurial activity among their students. Reflecting the quote above their mission is to identify potential students for entrepreneurship and add to their skills to perform in entrepreneurial context. There is also an ample array of research looking at the efficiency of 
such programs in what comes to the amount of new businesses created and improvement in e.g. entrepreneurial thinking and mindset

Parallel to the overall interest in entrepreneurship and its education, startup has become a common word across nations, regions, cities and universities in them. In comparison to any new enterprise, a startup operates in an environment of utmost uncertainty, but also in an environment where there is a potential for rapid growth and internationalization due to scalability. As Aulet and Murray (2012) pointed out: "Not all jobs are created equal ... Unfortunately, many small businesses employ the founder and spouse or just a handful of workers. These companies create jobs, but typically provide lower-than-average wages and benefits. Contrast these companies with the innovation-driven enterprises who seek to address global markets - offering goods and services based on substantial innovation linked to an understanding of a specific market."

The Communication from the EU Commission titled "Implementing the Community Lisbon Program: Fostering entrepreneurial mind-sets through education and learning" (COM, 2006) declares that entrepreneurship is a key competence for growth, employment and personal fulfilment and that the education systems can greatly contribute to successfully addressing the entrepreneurial challenge within the EU.

Entrepreneurship is not only a need of society to individuals, it also fits well with many life goals addressed by the Y-Z-generations currently in university education or soon joining it. According to Eisner (2005) the Generation Y is the so far most technically literate, educated, and ethnically diverse generation in history. That generation wants intellectual challenge, needs to succeed, looks for those who will further its professional development, strives to make a difference and measures its own success. Meeting personal goals is likely to matter to Generation Y, as is performing meaningful work that betters the world and working with committed co-workers with shared values. The need for educational setups and processes to support growth-oriented entrepreneurship is coming from different stakeholders. If universities can develop a soil where both birth on nascent entrepreneurs-startup creation-as well as employability of students as employees to startups can flourish, the impact to the economic and employment development is notable. This study set to see if there are common characteristics between start-up entrepreneur and employee career paths. Some earlier studies (e.g. Brenner et al., 1991) have seen organizational employment and entrepreneurship as opposing choices.

This paper studies the career narratives (short career histories and projections) written by students who participated Supercoach ${ }^{\circledR}$ Entrepreneurial Training (SET) and/or High Tech Management programs in the International Business-program of JAMK University of Applied Sciences in Jyväskylä, Finland, and ended up to be working - at the time of narrative writing - working in technology-based start-up companies as employees or entrepreneurs.

The key objective of this research was to study processes through which an individual grasps the employment or/and entrepreneurial opportunity in a start-up context. Key research questions were: 
$>$ What are the factors (internal and external to university education) affecting the aforementioned career choices?

$>$ What factors have been the key drivers leading the respondents to the career path they are on?

> How do the respondents project their future career in their narrative?

> How is the employment/entrepreneurship path likely to continue?

In this research paper the next chapter 2 focuses on relevant research and literature to provide a framework for the study. Chapter 3 describes the methodological choices of the research and the implementation of the empirical data collection and analysis. The main results of the data analysis are provided in the chapter 4 , after which the conclusions are drawn in chapter 5 . The final chapter 6 discusses in a reflective mode the research and the generalizability of its results and points out the directions in which additional research would be needed and welcomed.

\section{Literature Review—Relation of Entrepreneurship and Employability}

This research focuses on the individual learning and development process as self-interpreted by a number of individuals who have a) participated in an entrepreneurship-oriented educational program; and b) been employed of self-employed (founded or joined as a co-entrepreneur) to a technology-based startup company. To say it shortly, the individuals whose career path narratives have been studied have obviously possessed and/or developed entrepreneurial and employability intention and characteristics.

Entrepreneurial programs in universities are wide-spread and consequently there is an ample array of targets and effectiveness measurements for such programs. As Kolvereid and Moen (1997) summarize, there has been 2 major streams in entrepreneurship research. One of psychological career theory, that sets the focal point to personality traits that are favorable for an entrepreneur-to-be but also relatively static and difficult to alter (e.g. Holland, 1985). The other one sees the career choice and development more as a dynamic process affected by the environment (information and people) of an individual (e.g. Prediger \& Vansickle, 1992). The latter school of thought suggests that modifying the educational context to entrepreneurial one can affect to the growth and success to entrepreneurship and individual entrepreneurs. Dyer (1994) attempted to bridge the two research traditions by adding to the concept of entrepreneurial growth the impact of role models. Connections with existing entrepreneurs in educational programs can have an effect on attractiveness of entrepreneurship as a career option.

Entrepreneurial traits targeted and measured across programs vary across studies. A typical example is the research of Gürol and Atsan (2006) where entrepreneurial characteristics amongst university students were assessed. The six traits assessed were: 1) need for achievement; 2) locus of control; 3) risk taking propensity; 4) tolerance for ambiguity; 5) innovativeness; and 6) self-confidence.

Another theoretical construct related to identification end exploitation or entrepreneurial opportunity is that of entrepreneurial mindset. Yoder and Klein $(2011,2013)$ point out that if 
the sole measurement of success of entrepreneurial education program is the rate of business creation by the learners, that target will imply a different educational program than when the key target of program design is the cultivation of an entrepreneurial mindset. The latter option may not yield immediate venture creation, but may produce entrepreneurial activity later on. It can also be utilized inside the frame of established company in the role of an employee, intrapreneurship. Intrapreneurship can be described for example like Antoncic and Hisrich (2001): "I. is entrepreneurship within an existing organization. It refers to a process that goes on inside an existing firm, regardless of its size, and leads not only to new business ventures but also to other innovative activities and orientations such as development of new products, services, technologies, administrative techniques, strategies, and competitive postures."

Yoder and Klein (ibid.) created solutions to assess the achieved outcomes in the mindset creation. In their work (on the KEEN program = Kern Enterprise Education Network) they had 7 different Mindset Learning outcomes whereas in a UIIN (University-Industry Interaction Network) workshop lead by Dr Paul Coyle in June 2015 there were 6 subsets of entrepreneurial mindset. See Table 1 for the comparison.

Table 1. Comparative look at the constituents of an entrepreneurial mindset

\begin{tabular}{|l|l|l|}
\hline & \multicolumn{2}{|c|}{ The constituents of Entrepreneurial Mindset (order not of importance) } \\
for a student to possess
\end{tabular}

As can be seen mindset-labelled issues can in fact relate closely to personality traits (Yoder \& Klein nr. 4, Coyle nr. 3), values (Y \& K nr. 6, nr. 7) as well as to cognitive (Y \& K nr. 2, Coyle nr. 1) and "hard" business skills (Y \& K nr. 3, nr. 5, Coyle nr. 2, nr. 4). Many of the issues listed 
in these 2 approaches would also work in a corporate employment setting i.e. as mindset of an employee in a modern firm.

Kirby (2004) has in his research stated that successful entrepreneurs possess a set of personal skills, attributes and behavior. These go beyond the purely commercial dimensions and can be called meta-skills that affect the overall activity of an individual. These multipole skills can be utilized in the specific phases of entrepreneurship. In this view entrepreneurship is seen more as a process than as a one-off career decision. Thus entrepreneurship should be understood and studied as a cognitive and evolving process (Eckhardt, 2003). There has been a long and wide supply of growth stage theories to explain the growth of firms and linking the growth of the entrepreneur(s) in them (e.g. Churchill \& Lewis, 1983; Greiner, 1972; and recently Marmer et al., 2011). The criticism to the stage-based approach by Levie and Liechtenstein (2010) proposes that growth of entrepreneurial firms and entrepreneurs do not follow pre-determined paths. Instead, the evolution of an entrepreneurial company should be seen as movement between different dynamic states. Entrepreneurial firms can and they do resources in a new way when new opportunities arise. This skill of opportunity identification and exploitation is often cited in recent research, ignited by Shane and Venkataram (2000).

Employability - in its turn - is a wide concept. The core meaning of employability whether or not graduating students have the characteristics that are of demand when organizations are recruiting new human resources.

Studies of employer needs have repeatedly stressed the high weight they give to "personal transferable skills" (Dearing Committee, 1997). They are looking for graduates possessing not only specific skills and knowledge, but with the ability to be proactive, see and respond to problems. Increasingly employers are searching for graduates who are balanced in the sense that they have a good academic achievement and possess 'soft skills' such as communication skills, problem solving skills, interpersonal skills and are flexible. These 'soft skills' (also known as 'employability skills') are foundation skills that apply across the board, no matter what job the employee is performing (Lawrence, 2002). The need for employees with multi skills is much higher in small and medium enterprises (SMEs) (Lange et al., 2000). Unlike smaller businesses, larger organizations traditionally have hierarchical structures that allow the employees to have fixed jobs (e.g. Burns, 1984). Thus, the employees can stay specialized in a specific area. The scenario is different in smaller organizations that are flatter in structure and less hierarchical. Thus, the employees are required to be multi-skilled and to be able to perform varying tasks. The skills that Brewer (2013) in her report published by ILO identified as crucial for the new job market were summarized in the following points: flexibility/ adaptability; effective communications skills; problem solving; creativity; interpersonal skills and teamwork.

Startup firms possess a challenging field to employability. This can be seen in the classical definitions of startups by Ries (2011) "a startup is any organization aiming at creation of new product or service in conditions of extreme uncertainty" and Blank (2010) "a startup is a temporary organization looking for a scalable and repeatable business model". These definitions point out that in a start-up firm the amount and quality of resources needed varies a 
lot during the start and growth phases of the company. This naturally stresses the importance of capabilities like multitasking, flexibility etc., as organization and jobs do not settle down.

The two concepts, entrepreneurship and employability are not opposite ends of one's position in the world or work. According to Judd et al. (2015), entrepreneurship offers an alternative means through which graduates can obtain employment. By working with entrepreneurs the educational institutions can impact their students' employability to entrepreneurial firms. Engaging students with enterprises offers educators to "activate a feedback loop" in order to understand what is occurring within the marketplace and alter curriculum accordingly.

According to Judd et al. (2015), a particular challenge has emerged in the technology sector, since "innovation is truly outpacing the amount of jobs that we have." Employers within this sector argue that graduates do not have the relevant hard skills required to work within industry. They however propose that students can tackle this challenge via participation in work experience programs throughout their degree, to embed hard skills that employers are looking for.

To synthetize the concepts and views of earlier research, this study makes the following assumptions:

$>$ The process in which individuals engage to entrepreneurial activity (as an entrepreneur or an employee in an entrepreneurial firm) is individual;

> The process contains issues of personality, values, skills, motivation and opportunity;

$>$ Environmental incidents and relations affect the process of entrepreneurial engagement;

$>$ The process of developing entrepreneurship preparedness and employability are at least partly sharing the same characteristics.

\section{Research Methodology}

This research combined the practices of conceptual research in the literature review and qualitatively oriented research in the empirical part. As was stated in the literature review, there was not a relevant model created in the earlier literature to lean on as a dominating theoretical framework. Instead, the research was of exploratory nature. The research was set to see whether a model-like process related of growth to entrepreneurship would emerge from the data collected. The object of the study was students from entrepreneurial program the author is well familiar with as an educator. This could naturally cause personal bias. Since the scope of this study was not to evaluate the programs the author has been involved with, the closeness of the author to the subject made it possible to identify and find the respondents whose career profile matched the quest for knowledge of the research.

As Ravitch and Riggan (2016) put it, the conceptual framework includes not only the relevant theoretical literature but aims at fitting into it also the findings of prior research as well as the researching authors own experience-based knowledge and commitments. Creswell (2013) notes that all researchers bring theories, frameworks and hunches in to their exploratory inquiries. These theories can be made explicit or they may be more subtle, not openly mentioned. In the literature review of this study the author made explicit the frameworks that 
have affected to the empirical part as well as explicitly addressed the hunch that there might be processual nature in the studied phenomenon - growth into entrepreneurship - but left the verification of the correctness of that hunch to the data collected and its analysis.

Conceptual framework is defined as "an argument about why the topic one wishes to study matters, and why the means proposed to study it are appropriate and rigorous" (ibid.). They also point out that frameworks tend to and even should change during the research process, as the knowledge of the researcher reshapes. From that viewpoint the research was rather an exploratory journey in the vast supply of frameworks that had connection points to the model searched for but did not had a high fit to the particular process-development into start-up entrepreneurship and employment-studied. The author aimed at creating a first-cut model to be tested later on with wider samples, in case it shows such model would in surging from the data.

The exploratory approach to scan, compare and synthetize (whenever possible) represents the "reason" element of the framework building in this research, following the ideas of Ravitch and Riggan [ibid.]. The element of "rigor" means choosing a suitable method and using rigorously for creation of knowledge out of data collected.

The approach used in this research was of inductive nature. Inductive methods suit well to instances where there is not yet a model or theory to be tested/proven. Instead the researcher is aiming to generate if from the data gathered (Eisenhardt et al., 2016). The research project proceeded from collecting the primary data from the objects of study to recognizing patterns that would then serve as basis for model creation. The process also included critically reviewing the identified issues against conceptual and process models of prior research and proposing improvements or modifications. As it goes for inductive approach, models and concepts presented in the literature review can affect but not decide nor limit what the researchers will find when collecting primary data (Malhotra \& Birks, 2005).

Qualitative research method was chosen due to the opportunities it gives to the researcher to develop a complex, holistic picture of the target (Creswell, 1998). The form of the qualitative data collection was chosen to be that of narrative research. According to Nygren and Blom (2001) analysis of short reflective narratives provides a shortcut to understand deeper of both the narrative and the narrator. Narrative analysis is an approach that is well suited to the exploration of how people make sense of their experiences (Clandinin \& Connelly, 1994). However, in addition to the interest in analyzing sense-making, narrative analysis also enables the researcher to study how people order and tell, or rather structure their experiences (Coffey \& Atkinson, 1996). Nygren and Blom (ibid.) also admit there are downsides in narrative analysis as a method: The method using written narratives has potential risks of 'over-interpretation', and the loss of the 'midwife' effect that can appear in an oral interview - the opportunity for a discourse offering an opportunity to evolution of ideas during interviews is lost.

Magana (2002) summarized the key questions of a narrative-based research as follows: "What does this narrative or story revel about the person and world from which it came? How can one interpret this narrative so that it provides an understanding of and illuminates the life and culture that created it? Magana (ibid.) also states that emphasis of phenomenology on 
understanding lived experience and perceptions of experience impact the narrative research. The central idea of narrative analysis is that stories and narratives offer especially translucent windows into cultural and social meanings.

As Polkinghorne (2011) coined, a narrative is an individual cognitive process that gives meaning to temporal events by identifying them as parts of a continuum. To have the same focus the researcher decided to use the pre-planned pointing out the potential issue areas to be treated in narratives so that individual narratives would be more comparable and recognition of patterns more likely. Some respondents clearly structured their narrative based on the researcher-originated structure, whereas some formatted their narrative more to a free-format text.

The 6 narratives were analyzed in April-May from students that previous to their start-up employment or (in some cases: and) entrepreneurship have been engaged in one or two of the following learning settings at JAMK University of Applied Sciences, Jyväskylä Finland:

$>$ Supercoach Entrepreneurial Training ${ }^{\circledR}$ : An intensive 8-week entrepreneurial coaching program bringing together first-time knowledge/technology based entrepreneurs as case owners and business students as assistant coaches to them (assisting the course instructors in case coaching)

> High Tech Management-program: A full-semester specialization module focusing on technology business and start-up activity in that field.

Previous research (Saukkonen, 2014; Saukkonen et al., 2016) has indicated that these collaborative learning set-ups have fostered students' networks, entrepreneurial skills (measured via self-efficacy) and networks, adding to their entrepreneurial opportunities more than other individual stand-alone courses in the same institution.

The narratives were 500 to 800 words in length, and the type of the narrative can be seen as semi-structured, as the researcher gave some key viewpoints to be considered when writing the narrative. The task for narrative writers was given in some short sentences both pointing out the target but not indicating weighting of different issues nor limiting the issues to be just those earlier research had identified.

The task given to the authors of narratives was:

"Career Narratives of Students in entrepreneurial programs-case: JAMK's Launch Pad and/or Hi Tech Management-programs

To join as an informant - could you please write - MS Word or compatible - a short narrative of your learning and career development that has taken you where you are and have been. May be fun and rewarding also for yourself ...

Narratives are always of personal nature, but at least consider following points to reflect:

$>$ Can you recall when did you have for the first time entrepreneurial (or joining a start-up as an employee) intentions, has it been a goal or just an opportunity that appeared? 
$>$ Can you pinpoint some key experiences, courses meetings and incidents that have lead you to the way in which you are now_-both inside and outside formal studies?

> What role have personal relations, role models etc. had to you development?

$>$ Why do you think you are in the career track you are now? How did you choose the business to join or found, or did the company or the opportunity "choose you", why and how?

$>$ What is your prediction for the further career, in which kind of a role you picture yourself in next 5-10 years?

$>$ What are the key learnings you have gained as a start-up entrepreneur and/or employee and where can you utilize them the best in the future?

I would appreciate having your 1-2 page freeformat stories by $5^{\text {th }}$ April, 2016".

The narratives were analyzed by searching for keywords pointing to the key concepts identified from previous research. Since the sample was small in number of respondents, the aim was not to calculate the frequency of similar statements appearing in the data. Instead the aim was to look at the spectrum of optional routes and potential cause-effect linkages to start-up entrepreneurship/employment to be potentially subjected to quantitative research in the future.

Data analysis consisted (in the absence of relevant prior model) with an open-ended reading of the collected data (narratives). Once the researcher started recognizing content-wise similar statements and then making implicit the model that was emerging (see next Chapter; Results). Next the content of the narratives were coded based on the model elements, in the results section the model based on stages of development is introduced, as well as issue areas mentioned (and how often they were expressed in the individual narratives) that belong to the identified stages. To give the readers a clearer picture of the reasoning of the researcher, illustrative examples (word-to-word excerpts) from the narratives making issue areas are also shown.

\section{Results}

The analysis of the narratives showed that the road from a student to start-up entrepreneur and employee is to a certain extent individual for every person, there are some recognizable patterns. One pattern emerging from the research data suggests that entrepreneurship and employment to entrepreneurial companied can be better understood via a lens that seen entrepreneurship as an evolutionary process. The general evolutionary process includes different stages that students join at different points and with different intensity - and proceed at different pace to next stages.

Levie and Lichtenstein (2010) commented after studying a multitude of staged models companies: Stages of development include different things for different cases, and rather than a step-by-step model, evolutionary development is of constant moving between different dynamic states - sometimes even moving "backwards" in sequential path due to trial-error based learning, pivoting or new opportunity recognition. 


\section{Macrothink

One can match the findings of Levie and Lichtenstein to the view of Churchill and Lewis (1983) that development of a new venture cannot and shouldn't be separated from the development of its owners/managers. Logically, it can be assumed that the development of a student into a start-up entrepreneur and/or employee follows the same type of evolutionary path-with movements to many directions.

The stages identified in this research were (summary of key incidents/processes per stage and appeal factors in Table 2):

1) Pre-study: Exposure to and consideration of entrepreneurial opportunities before joining University;

2) Standard Studies: Getting exposed to entrepreneurial thinking and principle via coursework;

3) Project work: Performing real-life assignments to companies (or own business initiative);

4) Active start-up work: Full-time and effort work as start-up entrepreneur or employee;

5) Senior Expertise: Spreading knowledge, investing time and money to new initiatives.

It should be noted that individuals pass the stages in very different timescales, and some may have various stages on going with different business initiatives. Crucial point for the "birth" of new start-up entrepreneur/employer seems to be the Project Work-stage, where the matches of values, personalities and capabilities get tested in real-life environment. This stage also represents the shift from observing entrepreneurs and oneself, being informed of and exposed to entrepreneurship efforts to practicing them. That is also the stage in which all 3 of the key issues areas of Networking, Trying, Learning (see Table 4, later) come together.

In Table 2 the key issues (incidents and activities relevant to the topic) per stage identified are placed into the staged framework, also a figure in parenthesis is added to inform how many of the 6 respondents referred to the issue in their narrative. The same applies to Table 3, where the identified appealing factors (of entrepreneurial engagements) per stages are listed. 
Table 2. The staged model of students' entrepreneurial career development - critical activities and incidents (In parentheses a number indicating how often the issue area appeared in the narratives)

\begin{tabular}{|c|c|c|c|c|}
\hline Pre-Study stage & $\begin{array}{l}\text { Standard } \\
\text { Studies-stage }\end{array}$ & Project-work stage & $\begin{array}{l}\text { Active start-up } \\
\text { work stage }\end{array}$ & $\begin{array}{l}\text { Senior } \\
\text { Expertise-stage } \\
\text { (projected) }\end{array}$ \\
\hline $\begin{array}{l}\text { Observations of } \\
\text { own personality } \\
\text { and its relation to } \\
\text { work (1) }\end{array}$ & $\begin{array}{l}\text { Basic } \\
\text { knowledge of } \\
\text { entrepreneurship } \\
\text { (6) } \\
\text { Network creation } \\
\text { with peers (2) }\end{array}$ & $\begin{array}{l}\text { Working on } \\
\text { assignments for } \\
\text { firms (5) } \\
\text { Working on own } \\
\text { idea incubation (1) } \\
\text { Networking outside } \\
\text { peer group (6) } \\
\text { Opportunity } \\
\text { recognition (5) }\end{array}$ & $\begin{array}{l}\text { Full member of } \\
\text { core venture team } \\
(4) \\
\text { Full time work (2) } \\
\text { Idea } \\
\text { implementation (6) } \\
\text { Growing the } \\
\text { business (6) }\end{array}$ & $\begin{array}{l}\text { Board } \\
\text { membership (2) } \\
\text { Mentoring } \\
\text { emerging } \\
\text { entrepreneurs (3) } \\
\text { Investing (2) } \\
\text { Consulting (1) } \\
\text { Expertise function } \\
\text { in established } \\
\text { company (3) }\end{array}$ \\
\hline
\end{tabular}

Table 3. Appealing factors of entrepreneurial engagement per stages (In parentheses the number indicating how often the issue area appeared in the narratives)

\begin{tabular}{|c|c|c|c|c|}
\hline Pre-Study stage & $\begin{array}{l}\text { Standard } \\
\text { Studies-stage }\end{array}$ & Project-work stage & $\begin{array}{l}\text { Active start-up } \\
\text { work stage }\end{array}$ & $\begin{array}{l}\text { Senior Expertise } \\
\text {-stage }\end{array}$ \\
\hline $\begin{array}{l}\text { Invididual } \\
\text { decision-making } \\
\text { (1) } \\
\text { Independency (1) }\end{array}$ & $\begin{array}{l}\text { Opportunity } \\
\text { to work with } \\
\text { like-minded } \\
\text { people (3) }\end{array}$ & $\begin{array}{l}\text { Interest to business in } \\
\text { question (assignor) (6) } \\
\text { Personalities matching } \\
\text { (5) } \\
\text { Self-awareness of } \\
\text { efficacy in } \\
\text { entrepreneurial tasks (4) }\end{array}$ & $\begin{array}{l}\text { Growth (6) } \\
\text { Being a member of } \\
\text { a team (5) } \\
\text { Ability to have an } \\
\text { impact (6) }\end{array}$ & $\begin{array}{l}\text { Sharing } \\
\text { knowledge (5) } \\
\text { Using gathered } \\
\text { knowledge for } \\
\text { new cases (4) } \\
\text { Encouraging } \\
\text { others (3) }\end{array}$ \\
\hline
\end{tabular}

In the following Tables 4 (2 first stages that focus on observations and connections) and 5 (3 remaining stages focusing on doing entrepreneurial efforts) the author has collected the statements form the narratives in order to show how respondents formulated their own interpretation of their personal development. The original comments have been modified only 
in phrase structure for readability.

Table 4. Chosen excerpts from the narratives highlighting issues linkable to two first identified stages $=$ pre-study and standard study stage

\begin{tabular}{|l|l|}
\hline Pre-Study Stage & $\begin{array}{l}\text { "I do not like taking orders from random people. I figured out when at } \\
\text { school, in my first work and later in other work occasions. Therefore, } \\
\text { when } 20 \text { years old, I realized the only way to get around is to become a } \\
\text { boss of my own" } \\
\text { "My first entrepreneurial ideas came after a summer job I got when 17. I } \\
\text { could not see working for someone as a way of making money for other } \\
\text { things in life. I was ready to work long hours and take projects in other } \\
\text { cities, hanging out with colleagues on my free time" }\end{array}$ \\
\hline Standard Studies-Stage & $\begin{array}{l}\text { "It was more of a coincidence and an opportunity that appeared. I was } \\
\text { talking to a person who just had found a company and through the } \\
\text { discussion I got interested and eventually involved in the company" } \\
\text { "I already had a plan to change the school after the } 1^{\text {st }} \text { year. However, } \\
\text { after the courses started I had a chance to see what potential I can } \\
\text { develop with support to entrepreneurship we had. I decided it was the } \\
\text { place to be. I was lucky to be coached by an incubator already at the } 2^{\text {nd }} \\
\text { semester of studies. }\end{array}$ \\
\hline
\end{tabular}




\section{Macrothink}

Table 5. Chosen excerpts from the narratives highlighting issues linkable to three last identified stages $=$ project-work, active start-up work and senior expertise

\begin{tabular}{|c|c|}
\hline Project Work-stage & $\begin{array}{l}\text { "In a way I chose the company to work with, as it was close to values I } \\
\text { have. I always wanted to do something meaningful. On the other hand the } \\
\text { company chose me because I had asked for the opportunity and also shown } \\
\text { during the group work for the company that I am capable" } \\
\text { "The opportunity found me!" } \\
\text { "If I could not enjoy the job and the people, I could not do it for money. } \\
\text { After all it's the pursuit of happiness that drives us forward" } \\
\text { "The experiences of participating to real-life business activities encouraged } \\
\text { me to move forward" }\end{array}$ \\
\hline Active start-up work & $\begin{array}{l}\text { "The great thing is that you are not a "robot" employee but instead a } \\
\text { creative partner facing challenges with the team" } \\
\text { "Having the possibility to develop my own responsibilities and attend to } \\
\text { different training related to them is and was both interesting and rewarding } \\
\text { for the work and self-development" } \\
\text { "I notice that I usually find common language with people of all sorts of } \\
\text { age, social status and occupation. That allows me to create large contact } \\
\text { networks relatively fast, and "connect the dots" within the network. }\end{array}$ \\
\hline $\begin{array}{l}\text { Senior expertise } \\
\text { (projected) }\end{array}$ & $\begin{array}{l}\text { "I want to build, make an impact and encourage other to do the same" } \\
\text { "If all goes well with the current company, I will make an exit in 4-5 years. } \\
\text { And everything is possible after that" } \\
\text { "I picture myself in a manager position in the next 5-10 years. I should be } \\
\text { an expert in our field by then" } \\
\text { "I picture myself in the sales and marketing or business development of a } \\
\text { SME/Startup business. It would be great to have another chance of being } \\
\text { part of a new start-up in the future as well" } \\
\text { "In 1o years, I will open a small garage and do nothing but play sports and } \\
\text { restore classic European cars }-) "\end{array}$ \\
\hline
\end{tabular}

The last request (in the accompanying message to the narrative writers) was to summarize their key learnings from the study and professional path they have travelled so far to get to their present position. The key takeaways or lessons learned concentrated into 3 areas:

1) Networking — building relationships and getting tasks to perform; 
2) Trying — showing the skills and "tasting" real-life business, build-up of self-efficacy;

3) Learning - ability to analyze the solutions or own work and with others.

Table 6. The key learnings from entrepreneurial/start-up careers-summary from the narratives

\begin{tabular}{|c|c|}
\hline The Issue Area & Illustrative excerpts from narratives \\
\hline 1) Networking & $\begin{array}{l}\text { "Nurture networks and relationships" } \\
\text { "Let's just say connections are very valuable and one should never burn bridges } \\
\text { as one never knows where those connections may be needed in the future" } \\
\text { "When I realize that one of my looking e.g. for a buyer, I do have potential ones } \\
\text { "in my pocket" } \\
\text { "Now the grand finale of my narrative: Network, spar with people, talk about } \\
\text { your ideas-and go for it" }\end{array}$ \\
\hline 2) Trying & $\begin{array}{l}\text { "... you have to accept that learning is done by trial and error because none has } \\
\text { done it before!" } \\
\text { "I am still not sure if what I do is what I want to be doing, so I constantly keep } \\
\text { looking for new opportunities. I try to understand for myself what it is that really } \\
\text { brings me joy" } \\
\text { "If you have an idea of being entrepreneur during studies, take it further. Plan a } \\
\text { business of some kind, even when it would be something that would never start" }\end{array}$ \\
\hline 3) Learning & $\begin{array}{l}\text { "Hunger for learning" } \\
\text { "Personally have some niche and specialize in 1-2 areas/functions. They will } \\
\text { become your personal elevator pitch. Yet be willing to wear many hats" } \\
\text { "I think most of the key capabilities and lessons can be put in use in basically any } \\
\text { business" } \\
\text { "Learning is a continuous process" } \\
\text { "Still, in every project and job I've gone into I've learned tons of new things" }\end{array}$ \\
\hline
\end{tabular}

\section{Conclusions}

Based on the results achieved, it seems obvious that pre-determination of becoming an entrepreneur or a start-up employee is not a prerequisite to educate students to working in new 
ventures. What seems fruitful practice for all parties is making student cohort to collide with the existing entrepreneurs and starting to work with or for them with real life tasks. This seems to be crucial to bonding of the two parties; a student gets a realistic image what the business and people running it are and the employers or co-entrepreneurs get a view of the efficacy and style of work of a student.

Going through one-by-one the original aims of the research process one can conclude that:

1) What are the factors (internal and external to university education) affecting the aforementioned career choices?

The role of "touch" got emphasized: The students driven to entrepreneurial career have had personal touch with the real-life entrepreneurs as well as to the issues the companied managed by these entrepreneurs are dealing with in their business practice

2) What factors have been the key drivers leading the respondents to the career path they are on?

Core appeal factors into the entrepreneurial career has been the findings of self-efficacy and personality match to the environment: Meeting people with the same mode of thinking and acting as well as being able to find one can succeed in entrepreneurial efforts and assignments fortifies the appeal. There few just individual remarks of birth of entrepreneurial ideas and identity before embarking to business studies, mostly the growth was started inside the time as an enrolled student and based on activities within study time.

3) How do the respondents project their future career in their narrative?

Entrepreneurship and working in entrepreneurial has stickiness; The respondents did not attach their identity solely to the company or business they are currently in, but showed clearly their career is more likely to continue in that type of environment. However, altogether 3 respondents visioned an opportunity to leverage the gained expertise in the corporate context. Entrepreneurial skills are experienced to be transferable skills that can be used beyond the limits of entrepreneurial organizations.

4) How is the employment/entrepreneurship path likely to continue?

Respondents showed that they have a vision and desire of utilizing the experience gained into the development of new entrepreneurial and growth efforts (in the roles of consultant, board member, advisor) as a logical continuation of their career. This phenomenon could be called "passing on entrepreneurship", a parenthood attitude towards other emerging entrepreneurs.

For entrepreneurship educators it seems important to recognize the stage in which individuals are in, and how they can best be supported to move on. The results of this study have potential of indicating what kind of processes and actions would support the development process.

Since the sample of this survey was small, it does not allow to make any statistical generalization of the results. What can be stated, however, is that entrepreneurship education and support set-ups that in one way or another support the 3 key issue areas identified: Network-Try-Learn, are likely to offer the most fertile ground to build-up of an entrepreneurial 
mindset. This mindset can be utilized both in an entrepreneur or employee roles in new ventures.

\section{Discussion}

There is multitude of scholarly papers discussing the criteria for qualitative (research) goodness including concepts. One criteria is catalytic validity (Lather, 1986) i.e. did the research accomplish its intention to catalyze a change. Another indicator of quality is that of empathetic validity (Dadds, 2008) i.e. did the research act as a change agent for relationships between people. Richardson (2000b) has name the quality indicator of crystallization i.e. can the results be illustrated creatively in a way that reflects deeper thinking, Altheide and Johnson the one of tacit knowledge (1994) i.e. was the research able to offer a lens into knowledge that has been difficult to express and formulate. One more quality indicator is transferability (Lincoln \& Guba, 1985) i.e. how can the results of the research be applied in a different context, and so on. The concepts for qualitative excellence clearly illustrates the creative complexity of the qualitative methodological landscape (Tracy, 2010). For an individual research paper as the one in hand the goodness analysis against abovementioned criteria would be limited to the potential of the research to act as described in the criteria. The results obtained make it reasonable to state that the research served at least for crystallization and tacit knowledge-dimensions. The catalytic validity and empathetic validity depend on the people and institution "altered" to the knowledge created, and can be assessed only after time.

One additional prerequisite to research quality is data saturation. Interviews are one method by which one's study results reach data saturation. Bernard (2012) stated that the number of interviews needed for a qualitative study to reach data saturation was a number he could not quantify, but that the researcher takes what he can get. Moreover, interview questions should be structured to facilitate asking multiple participants the same questions, otherwise one would not be able to achieve data saturation as it would be a constantly moving target (Guest et al., 2006).

In this research the role of qualitative interviews in the abovementioned quality considerations can be viewed taken by the researcher's call for narratives (suggesting topics to be covered, equivalent to research questions) and narratives written in return (equivalent to answers to research questions. As Sandelowski (1991) points out, the reliability of an individual is not easy to prove nor deny, as they present in a positive case a "true fiction" i.e. they represent an interpretation of an individual on how things unfolded and what were the cause-effect connections behind them. Also this research assumed the narrative authors had no purposeful agenda behind their text. The differences in the narratives despite (the targeted) similar background and status of the respondents seems to prove the narratives do reflect individual and personal experience. On the other hand, by limiting the respondent pool to a narrow selection of people sharing the same status in terms of the research aims was done in order to improve the odds of finding some similarities and patterns. Those patterns allow the researcher to propose a prism through which the processes involved in start-up entrepreneurship and employee career path can be understood. As presented in the results chapter (Chapter 4 ) the data obtained from narratives was saturated enough to allow outlining 
an evolutionary model to which the findings from respondents' narratives fit in.

The respondent sample consisted of individuals who had taken the opportunity to be employed or entrepreneurially self-employed in start-up companies, i.e. were positive examples from the point of view of the learning processes focusing on entrepreneurship and start-up business. The common patterns found in the 6 narratives studied gives ideas of the critical drivers and success factors leading to start-up entrepreneurship and employability, giving thus guidance to designers of entrepreneurship programs in- and outside academia.

At the same time, this type of career paths represent a minority of the students that have passed the educational programs in scope. Even though the two entrepreneurial programs can be considered to be of a masterclass type (relatively small in size, high-intensity and high engagement) and offering the same opportunities of networking, skill demonstration by live projects etc. to all participants, majority of the students do not become entrepreneurs nor employees in start-up companies. This is a common phenomenon, the entrepreneurial intentions turn into actual implementation of a new business to a relatively low conversion rate. For example in Kolvereid's research in Norway in 1996 i.e. a long while before the current start-up boom and where the population was similar to this study, undergraduate students of business, approximately $43 \%$ of students preferred entrepreneurship over organizational employment as a career choice, whereas $37 \%$ would go for the employment path over entrepreneurship (and 20\% remained undecided). These levels of entrepreneurial intention were much also in studies in other societal contexts like US (Sandholz, 1990) and UK (Curran and Blackburn, 1989). Despite the high level of intentions and wishes, the actual share of graduates who start their own business typically varies between 1 to $10 \%$ of total graduate population (Kolvereid \& Moen, 1997). Research on the nonentrepreneurs' (= organizationally employed) subjective interpretations of their own different career paths would deepen the knowledge on the subject: are there dispelling factors in entrepreneurship and start-up environment, or are there some intervening factors and opportunities that attract people away from their stated intentions?

The research in hand is based on relatively rare basic assumption that (start-up) entrepreneurship and employment—via employability—are not opposite ends of a line, but rather have many similarities. As in many of the cases studied, employment or assigned project-type of work has led to employment and turned with time to co-entrepreneurship. This kind of evolutionary development of employee-to-entrepreneur path is still under-researched. The very basic nature of start-up business underlines the concepts of scalability and growth. This also means that these companies need to recruit and employ. The environment to which they seek employees is largely different from established companies, thus requiring specific mindset and skills. The focus of start-up research has been in the crucial stakeholders, the entrepreneurs, but the role of start-up employees both should gain more interest and weight both in research and education.

The results of this research suggest that the growth of an entrepreneur and an employee likely to join an entrepreneurial company is a process that happens in the intersection of many approaches. There are stage- and state-based models of new business growth (including such 
concepts as inception, validation, growth, maturity) (e.g. Greiner, 1972; Marmer et al., 2011), stage-based models of individual growth as human (that includes stages of childhood, adolescence, parenting etc.) (e.g. by Johnson-Hanks, 2002) as well as stage-based models of development of an innovative individual, the core essence of growth and entrepreneurial opportunity and growth (including stages of copying, craftsmanship, discovery) (Root-Bernstein, 1989).

Extended research with wider samples and longitudinal research on entrepreneurial careers containing elements from the abovementioned various frameworks could show the way for constructing entrepreneurship development programs of impact and lasting value.

\section{References}

Altheide, D. L., \& Johnson, J. M. (1994). Criteria for assessing interpretive validity in qualitative research. In N. K. Denzin \& Y. S. Lincoln (Eds.), Handbook of qualitative research (2nd ed., pp. 485-499). Newbury Park, CA: Sage.

Antoncic, B., \& Hisrich, R. D. (2001). Intrapreneurship: Construct refinement and cross-cultural validation. Journal of Business Venturing, 16(5), 495-527. https://doi.org/ 10.1016/S0883-9026(99)00054-3

Aulet, B., \& Murray, F. (2012). Not all jobs a created equal. The Boston Globe [Online 17.10.2012]. Retrieved June 5, 2015, from http://www.bostonglobe.com/opinion/2012/10/16/ not-all-jobs-are-created-equal/tO1N2PsdJne6Qaw9MYIiYN/story.html

BBC. (2013). Are entrepreneurs born or can they be taught? BBC News [By Sarah Treanor, Online 3.7.2013]. Retrieved May 15, 2016, from http://www.bbc.com/news/business23157638

Bernard, R. H. (2012). Social research methods: Qualitative and quantitative approaches (2nd ed.). Thousand Oaks, CA: Sage.

Black, N. (1994). Why we need qualitative research. Journal of Epidemiology and Community Health, 48(5), 425. https://doi.org/10.1136/jech.48.5.425-a

Blank, S. (2010). What's a Startup? First Principles [Online 25.01.2010]. Retrieved June 1, 2015, from http://steveblank.com/2010/01/25/whats-a-startup-first-principles

Brenner, O. C., Pringle, C. D., \& Greenhaus, J. H. (1991). Perceived Fulfillment of Organizational Employment versus Entrepreneurship: Work Values and Career Intentions of Business College Graduates. Joumal of Small Business Management, 29(3), 62-74.

Brewer, L. (2014). The Top 6 Work Skills Today's Employers Want. Social Europe Blog. Retrieved June 6, 2016, from http://www.socialeurope.eu/2014/04/work-skills

Burns, B. (1994). The Weaknesses in the Current Trends in Training Development in Relationship to Small Business in Scotland: Report to the Chief Executive of Scottish Enterprise. Aug. 11, Ayborne.

Churchill, N. C., \& Lewis, V. L. (1983). The five stages of small business growth. Harvard 
Business Review [Online]. Retrieved May 5, 2015, from http://www.researchgate.net/ profile/Virginia_Lewis2/publication/228315536_The_Five_Stages_of_Small_Business_Gro wth/links/00b495163f77e0bf82000000.pdf

Clandinin, D. J., \& Connelly, F. M. (1994). Personal Experience Methods. In N. K. Denzin \& Y. S. Lincoln (Eds.), Handbook of Qualitative Research. Thousand Oaks, CA: Sage.

Coffey, A., \& Atkinson, P. (1996). Making Sense of Qualitative Data. Thousand Oaks, CA: Sage.

COM (Commission of the European Communities). (2006). Implementing the Community Lisbon Programme: Fostering entrepreneurial mindsets through education and learning. Brussels. Retrieved form http://eur-lex.europa.eu/legal-content/EN/TXT/PDF/?uri=CELEX: 52006DC0033\&from=EN

Coyle, P. (2015). The Entreprenurial Mindset. Retrieved August 10, 2016, from http://profpaulcoyle.com/mindset.html

Creswell, J. (1998). Qualitative inquiry and research design: Choosing among five approaches. Thousand Oaks: Sage Publications.

Creswell, J. W. (2013). Research design: Qualitative, quantitative, and mixed methods approaches. Sage publications.

Curran, J., \& Blackburn, R. A. (1989). Young people and enterprise: A national survey. Kingston Business School.

Dadds, M. (2008). Empathetic validity in practitioner research. Educational Action Research, 16, 279-290. https://doi.org/10.1080/09650790802011973

Dearing Committee. (1997). Higher Education in the Learning Society. Report of National Committee of Inquiry into Higher Education. The Stationery Office, London.

Dearing Committee. (1997). Higher Education in the Learning Society. Report of National Committee of Inquiry into Higher Education. The Stationery Office, London.

Dyer Jr, W. G. (1994). Toward a theory of entrepreneurial careers. Entrepreneurship: Theory and Practice, 19(2), 7-22.

Eckhardt, J. T. (2003). Opportunities and entrepreneurship. Journal of Management, 29(3), 333-349. https://doi.org/10.1016/S0149-2063(02)00225-8

Eisenhardt, K. M., Graebner, M. E., \& Sonenshein, S. (2016). Grand challenges and inductive methods: Rigor without rigor mortis. Academy of Management Journal, 59(4), 1113-1123. https://doi.org/10.5465/amj.2016.4004

Eisner, S. P. (2005). Managing generation Y. SAM Advanced Management Journal, 70(4), 4.

European Commission. (2012). Report New skills and jobs in Europe: Pathways towards full employment. Retrieved from http://ec.europa.eu/research/social-sciences/pdf/new-skils-and -jobs-in-europe_en.pdf 
European Commission. (2015). Annual Report: Employment and Social Developments in Europe 2014. Retrieved from http://ec.europa.eu/social/main.jsp?catId=113

Fuchs, P. I., \& Ness, L. R. (2015). Are we there yet? Data saturation in qualitative research. The Qualitative Report, 20(9), 1408. http://nsuworks.nova.edu/tqr/vol20/iss9/3

Greiner, L. E. (1972). Evolution and revolution as organizations grow. Harvard Business Review (pp. 37-46).

Guest, G., Bunce, A., \& Johnson, L. (2006). How many interviews are enough? An experiment with data saturation and variability. Field Methods, 18(1), 59-82. https://doi.org/ $10.1177 / 1525822 \times 05279903$

Gürol, Y., \& Atsan, N. (2006). Entrepreneurial characteristics amongst university students: Some insights for entrepreneurship education and training in Turkey. Education + Training, 48(1), 25-38. https://doi.org/10.1108/00400910610645716

Holland, J. L. (1985). Makinz vocational choices: A theory of vocational Dtrsonalities and work environments (2nd ed.). Englewood Cliffs, NJ: Prentice-Hall.

Johnson-Hanks, J. (2002). On the limits of life stages in ethnography: Toward a theory of vital conjunctures. American Anthropologist, 104(3), 865-880. https://doi.org/10.1525/ aa.2002.104.3.865

Judd, M., Kinash, S., Crane, L., Knight, C., McLean, M., Mitchell, K., \& Lovell, C. (2015). Case studies to enhance graduate employability: Entrepreneurship.

Juhdi, N., Samah, A., Jauhariah, A., \& Yunus, S. (2006). Perceived employability skills of graduating students: Implications for SMEs. Retrieved June 3, 2016, from http://irep.iium.edu.my/24409/2/nurita_et_al_full_paper.pdf

Kirby, D. A. (2004). Entrepreneurship education: Can business schools meet the challenge? Education + Training, 46(8/9), 510-519. https://doi.org/10.1108/00400910410569632

Kleine, R., \& Yoder, J. (2011). Operationalizing and assessing the entrepreneurial mindset: A rubric based approach. Journal of Engineering Entrepreneurship, 2(2), 57-79

Kolvereid, L. (1996). Prediction of employment status choice intentions. Entrepreneurship: Theory and Practice, 21(1), 47-58.

Kolvereid, L., \& Moen, O. (1997). Entrepreneurship among business graduates: Does a major in entrepreneurship make a difference? Journal of European Industrial Training, 21, 154-160. https://doi.org/10.1108/03090599710171404

Lange, T., Ottens, M., \& Taylor, A. (2000). SMEs and Barriers to Skills Development: A Scottish Perspective. Journal of European Industrial Training, 24, 1. https://doi.org/10.1108/ 03090590010308219

Lather, P. (1986). Issues of validity in openly ideological research: Between a rock and a soft place. Interchange, 17(4), 63-84. https://doi.org/10.1007/BF01807017 
Lawrence, T. (2002). Teaching and Assessing Employability Skills through Skills USA. Annual Quality Congress Proceedings, ABI/INFORM Global (pp. 285-294).

Levie, J., \& Lichtenstein, B. B. (2010). A terminal assessment of stages theory: Introducing a dynamic states approach to entrepreneurship. Entrepreneurship Theory and Practice, 34(2), 317-350. https://doi.org/10.1111/j.1540-6520.2010.00377.x

Lezzerini, M., \& Usher, C. (2015). The StartUP Project-A New OER Gateway to Entrepreneurship in Europe. European Journal of Open, Distance and E-Learning, 18(1).

Lincoln, Y. S., \& Guba, E. G. (1985). Naturalistic inquiry. Beverly Hills, CA: Sage.

Magana, A. (2002). Variety in qualitative inquiry: Theoretical orientations. Qualitative research and evaluation methods (pp. 75-143).

Malhotra, N., \& Birks, D. (2005). Marketing Research: An Applied Approach (Updated 2nd European Edition). Edinburgh Gate, England: Pearson Education Limited.

Marmer, M., Herrmann, B. L., Dogrultan, E., \& Berman, R. (2011a). A New framework for understanding why start-up succeed. Start-Up Genome Report [Online]. Retrieved February 15, 2014, from http://gallery.mailchimp.com/8c534f3b5ad611c0ff8aeccd5/files/Startup_Genome _Report_version_2.1.pdf

Nygren, L., \& Blom, B. (2001). Analysis of short reflective narratives: A method for the study of knowledge in social workers' actions. Qualitative Research, 1(3), 369-384. https://doi.org/10.1177/146879410100100306

Polkinghorne, D. E. (1991). Narrative and self-concept. Journal of Narrative and Life History, 1(2-3), 135-153. https://doi.org/10.1075/jnlh.1.2-3.04nar

Prediger, D. J., \& Vansickle, T. R. (1992). Locating occupations on Holland's hexagon: Beyond RIASEC. Journal of Vocational Behavior, 40, 111-128. https://doi.org/10.1016/ 0001-8791(92)90060-D

Ravitch, S. M., \& Riggan, M. (2016). Reason \& rigor: How conceptual frameworks guide research. Sage Publications.

Richardson, L. (2000). Writing: A method of inquiry. In N. K. Denzin \& Y. S. Lincoln (Eds.), Handbook of qualitative research (2nd ed., pp. 923-948). Thousand Oaks, CA: Sage.

Ries, E. (2011). The Lean Start-Up. Crown Publishing.

Root-Bernstein, R. S. (1989). Who discovers and who invents. Research Technology Management, 32(1), 43-51. https://doi.org/10.1080/08956308.1989.11670574

Sandelowski, M. (1991). Telling stories: Narrative approaches in qualitative research. Image: The Journal of Nursing Scholarship, 23(3), 161-166. https://doi.org/10.1111/j.1547-5069. 1991.tb00662.x

Sandholz, K. (1990). MBA Attitudes (pp. 14-15). The College Edition of the National Business Employment Weekly, Spring. 
Saukkonen, J. (2014). Effects of project-based learning in education-Enterprise collaboration to learning experience and student engagement. Finnish Business Review. Retrieved December 16, 2014, form http://verkkolehdet.jamk.fi/finnish-business-review/files/ 2015/01/manucsript-4-revised-final-.pdf

Saukkonen, J., Nukari, J., Ballard, S., \& Levie, J. (2016). Start-up entrepreneurs and university students in a co-learning mode learning effects of a collaborative entrepreneurial coaching programme. Industry and Higher Education, 30(3), 224-238. https://doi.org/ $10.1177 / 0950422216653198$

Shane, S., \& Venkataraman, S. (2000). The promise of entrepreneurship as a field of research. Academy of Management Review, 25(1), 217-226. https://doi.org/10.5465/AMR.2000. 2791611

Tracy, S. J. (2010). Qualitative quality: Eight "big-tent" criteria for excellent qualitative research. Qualitative Inquiry, 16(10), 837-851. https://doi.org/10.1177/1077800410383121

Yoder, J., \& Kleine, R. (2013). Spreading the Fire: Broadening Faculty Support for the Entrepreneurial Mindset. Conference paper at NCIIA Open 2013, Washington D.C. Retrieved August 10, 2016, from http://nciia.org/sites/default/files/features/conference/2013/ papers/yoder.pdf

\section{Copyright Disclaimer}

Copyright for this article is retained by the author(s), with first publication rights granted to the journal.

This is an open-access article distributed under the terms and conditions of the Creative Commons Attribution license (http://creativecommons.org/licenses/by/3.0/). 